\author{
Łukasz Tischner (iD) https://orcid.org/0000-0001-8640-9648 \\ Uniwersytet Jagielloński \\ lukasz.tischner@uj.edu.pl
}

\title{
Postkolonializm. Potrzeba uważności
}

\section{Postcolonialism. The Need for Awareness}

W ostatnich latach wzrasta w Polsce zainteresowanie literaturą wywodzącą się z obszarów postkolonialnych. Pojawia się wiele przekładów nie tylko klasyki, ale także twórczości najnowszej, znacznie odchodzącej od kanonicznych schematów wyznaczanych przez Chinuę Achebe czy V.S. Naipaula. Publikacjom tekstów literackich towarzyszy namysł teoretyczny - literaturoznawcy i kulturoznawcy podejmują coraz bardziej specjalistyczną refleksję nad „postkolonializmem", czasem nawet kwestionując sens tego terminu.

W naszym numerze w jakimś stopniu abstrahujemy od sporów pojęciowych i skupiamy się na samej literaturze tworzonej na terenach postkolonialnych. Punktem wyjścia do dyskusji jest szkic Katarzyny Mroczkowskiej-Brand zatytułowany Postkolonialna lekcja uważności. Autorka postuluje w nim swoistą „etykę czytania”: analizę dzieł literackich, które pozwalają „wyrazić, jak mogło wyglądać życie kolonizowanych i kolonizujących na różnych etapach tych procesów”. Z jej tekstem polemizują znawcy kolonizowanych kultur, których poprosiliśmy o odpowiedź na kilka podstawowych pytań: dlaczego warto czytać literaturę postkolonialną?; czy decydująca jest motywacja etyczna - rodzaj zobowiązania, by wsłuchać się w głos tych, którzy wcześniej byli wykluczeni, czy też niezaprzeczalna literacka ranga dzieł należących do tego nurtu?; a może te dwie motywacje nakładają się na siebie? Dodatkowo sugerowaliśmy, iż zainteresowanie literaturą postkolonialną może brać się stąd, że powstające w tym nurcie powieści kwestionują radykalną autonomię literatury, ewokują pewne ideały życia (choćby negatywnie, ukazując ich niedosiężność) i tym samym wpisują się w klasyczny model powieści (Jane Austen, Victora Hugo, Fiodora Dostojewskiego, Alessandro Manzoniego, Bolesława Prusa), którego siłą była dynamika moralnych losów postaci. Może więc literatura postkolonialna przyciąga dziś czytelników znudzonych eksperymentami formalnymi i bezkrwistością (lub groteskowościa) bohaterów współczesnej euroatlantyckiej prozy? 
W swoim szkicu Katarzyna Mroczkowska-Brand wnikliwie komentuje trzy powieści: Tracks Louise Erdrich, La saison de l'ombre Leonory Miano oraz Pragnienie Richarda Flanagana, i pokazuje, jak ich autorzy zapisują ślady kultur ginących lub już utraconych. Apeluje tym samym o „uważnośc”, która pozwoli przywrócić pamięć o nich w edukacji i w przestrzeni publicznej. Ewa Łukaszyk polemizuje z ujęciem Katarzyny Mroczkowskiej-Brand, wskazując na wyczerpanie się typowo postkolonialnych paradygmatów i odwołuje się do tekstów mówiących o rzeczywistości „postpostkolonialnej” (między innymi Fouada Laroui, Tsitsi Dangarembga, Farisha Noora i Kalafa Epalangi). Joanna Ziarkowska podejmuje postulat „uważności” i opisuje projekt dekolonizacji edukacji dla Indian amerykańskich na przykładzie powieści Louise Erdrich LaRose i teorii dekolonizacji la papersona. Także Nina Pluta sięga do imperatywu „uważności”, by analizując powieści Maria Vargasa-Llosy, zająć się kwestią odzyskiwania zawłaszczonej reprezentacji. Ważnym uzupełnieniem tych rozważań są głosy Agaty Mrowińskiej, Henryka Siewierskiego i Agnieszki Gondor-Wiercioch. Ta pierwsza przypomina postać Aimé Césaire’a oraz założenia ruchu négritude i proponuje nowe odczytanie poematu Powrót do rodzinnego kraju. Dwoje pozostałych autorów tropi zaskakujące polskie wątki postkolonialne - Siewierski opisuje fenomen emigracji polskich chłopów do Brazylii (i jego literacki zapis), Gondor-Wiercioch z kolei pisze o powieściach Louise Erdrich, zestawiając dekonstrukcję stereotypów rdzennych Amerykanów z pogłębieniem portretów psychologicznych Amerykanów polskiego pochodzenia.

Literackim kontrapunktem dla powyższych rozważań jest close reading przewrotnego opowiadania Shermana Alexie Odlegtości, w którym - jak przekonuje Mroczkowska-Brand - proponuje autor mieszankę dystopii, science fiction, absurdu, groteski i horroru.

W numerze znalazła się także fascynująca rozmowa z Michałem Szczepańskim, synem Jana Józefa Szczepańskiego i edytorem jego monumentalnych dzienników, który niebywale szczerze i barwnie komentuje życie swego ojca i jego diarystyczny zapis. Polecamy dodatkowo recenzje „lektur obowiązkowych" - biografii Jana Józefa Lipskiego, studium Magdaleny Popiel o modernistycznych artystach oraz pierwszego opracowania o poezji Tomasza Różyckiego.

Eukasz Tischner Redaktor prowadzacy zeszytu 